\title{
Ethical Issues Analysis on the Financing Management of Media Companies
}

\author{
Sha Yanfei \\ College of Economics and Management, Huaiyin Institute of Technology, \\ Huaian 223001, China
}

\begin{abstract}
The ethical issues in the financing management of media companies is always existing. On the basis of analysing the characteristics of corporate finance in media companies, we use the enterprise financial ethics, stakeholders theory, corporate social responsibility theory and so as the analysis instruments to analyse ethical problems existing in the financing management of media companies. We analyse some issues, such as, concoct cheat money, high $\mathrm{p} / \mathrm{e}$ ratio issued, false financial information disclosure, vulgarized financing and so other ethical problems, and also analysing the reasons for these risen problems. In the cases, the ethical problems in financing management of some important media public enterprises have been stated. At last, in terms of improving financing environment, strengthening the financing responsibility of media companies, improving financial supervise, some media companies financial ethical countermeasures have been put forward.
\end{abstract}

Keyword: media companies, financing management, ethical issues.

\section{INTRODUCTION}

Capital and the capital operation are the substitutive characteristics of contemporary society. The essence of the emerge and development of contemporary society is an expansion process, which is based on the capital operation and expansion. Going public and having access to financing is one way of capital operation, which is widely used in media enterprises of foreign countries. However, in China, it is still in a stage of exploration. After our capital market has being born from nineties last century, listed company makes the use of financial fraud, fraud and some other means to seek gains for themselves, and harm the investor's interests. The distances between the financial interests and the social public interests become bigger and bigger, which brings the "burgeoning+transformation" a great roil. Making a general survey of the situation of accounting scandal in China, many kinds of market contradiction have been increasingly significant, and it causes a social consequence called "ethical conflict". When it becomes an universal phenomenon, it will causes substantive market risk. Chinese media companies are blooming, and their aim is getting money, so financial management becomes an important method for those companies to expand capitals. Media companies are responsible for special social responsibilities, when they are getting money, they often fall into a situation in which "economic man" and "social man" are inconsistent, and this has increased th whole society's focus. This article analyses the financial management problems in media companies in terms of ethics.

\section{REVIEW THE LITERATURE}

With the development of market economy and enterprise producing, enterprises' demands for capitals are becoming increasingly urgent. Financing difficulty is becoming an universal phenomenon, and enterprises' financing management is in conflict of social expectation. Wang Qing (2006) thought that, in financial activities, enterprises may not make unethical behaviours, if they make use of financial statement to forge, and make fictitious trading to raise capital. This kind of behaviour deeply harms the investor's interests, and causes ethical conflicts between listed companies and stakeholders. Wang SuLian, Ke Dagang (2006) provided that financial ethics is a kind of ethical ideas and ethical functions, through which, the finance makes some rules and regulations to integrate and adjust among different interest relationships. It is a behaviour rule used when adjusting different interests, and it is also a practice spirit used when the financial body grasps the financial activities. Chen Lihao, Wang Lihua (2008) thought that the main topic of enterprise financial ethics is: wether having bribery problem or not, wether having fair or not, wether having integrity or not, wether having appropriate price or not, wether having people oriented idea or not, wether having responsible for community responsibility or not, and so on. Zhangjuan (2005) pointed out that constructing appropriate financial supervision is a "due" model, and the key point is the rationality of itself.

Wei Yongzheng (2007) once tried to use "media causes company" or "company causes media" this kind of popular statement to explain the demarcation line of being legal and illegal in the area of media makes financing through outside worlds. The fundamental difference between these two is direction of outside venture's capital investment. Does it directly invest in media, or does it invest in the business part of media. Media and outside ventures engage in related activities, which is an elementary form of absorbing outside capitals. However, because this kind of elementary form is legal, financing from the society in the form of listed company also becomes legal. Zhong Yuanyuan (2009) thought that media corruption and the culture market goes into fawning are the two obvious problems in today's situation. The performance of media corruption is paid news and soft advertisement. Paid news is referred to as inappropriate goods-changing behaviour in the market. Soft advertisement is referred to as one kind of performance of paid news, owing to traditional 
advertisements have strong business colour and obvious persuasive intention, the consumers often hold the attitude of unbelieveable and suspecting. However, people prefer more to accept news than advertisements. In this exchange of unequal values, media will at last lose conscience and lose public trust.

\section{SPECIAL ANALYSIS OF FINANCING IN MEDIA COMPANIES}

\section{A. the main ways of financing in media companies}

Because of the fast development of internal film industry, the demand of financing demand is also increasing step by step. Each entertainment company aims to get finance through becoming listed company, and then scale up phase. The news of China Film Group, Huayi Brothers Media Corporation, Enlight Media, and Shanghai Film Group has been listed or rotating plate kept coming continuously. After internal rectification has been completed, Bona Film Group Ltd has changed its name to Boehner International Film Industry Group, and it expects to be listing in 2010 in America. These enterprises have stable industrial base and industrial structure, and the profit status is also considerable. Seeking financing by listing on the stock market is an important tool for them to expand the scale, and it is coming sooner or later.

Hunan TV \& Broadcast Intermediary Co., Ltd founded in January, 1999, and it is the first stock. This company's successful listing and developing brings demonstration effect for financial operation of media industry in China. At the mean time, listed " broadcast intermediary" collects many financial management experts, and making the financial ways into best use, which having certain financing representative.

It includes inter-media, cross-industry, and even international reconstruction. This kind of financing method is one way which is widely used when changing. In practical operation, enterprises need to control the initiative in this process, and when facing big changes, they can be able to improve the debt structure, which is a demand for the company to reduce their cost and make financing efficiently, and meet the investing behaviour's need.

After equity funds coming into China's media industry, it can not only brings capitals for the development of film enterprises, the more important thing is it can help them to establish a series of studio budget cases and auditing and financial management system. Through the capital party's strong control of capitals, it can guarantee that the cost can be controlled well.Now, the main PE existing in Chinese film are: IDG, A3, TWC, and so on. In addition to this, Hanneng, Yikai and so other PE also pay attention to the investment chances in it.

\section{B. social restraint in financing of media company}

21 century is an information times, the media industry is a combination of advanced technology, fashion mind, and fast information. From the global market, listed media company represents the industry which has the biggest imagination space and growth. When compared with traditional industry, media industry has relative monopoly, good value-added, and special profit earning model. From the domestic market, the development of listed media company has a relationship with the strategy of cultural industry revitalization.

The final aim of the media industry, not only is for freedom, and also not only for getting money. However, now many media industry prefer money than public interest, and even set economic interest as the only value orientation. This makes mass media becomes a tool for the adverser to make profits. The commercialization of media makes its aim as keeping the most common point in all directions, which is pure economic interests. This goes against with the media professional ethical original idea, because it goal is against with public interest.

\section{ETHICAL PROBLEM ANALYSIS ON FINANCING MANAGEMENT IN MEDIA ENTERPRISES}

\section{A. ethical problems}

A long period, pursuing for profits becomes the only goal of an enterprise. In order to pursue more profits, enterprises often do some unethical behaviours, which brings significant harm to the investor, and brings strong strikes to the society. Most surveys of enterprise's ethics are based on unethical phenomenon of financial practice, and then discussing the enterprises ethics problems. From the economic rational speaking, there is no problem for the enterprises to pursue lowest costs, however, this kind behaviour should be examined on its ethics of rationality. If the enterprises use ways like scientific financing mix or tax planning to get the aim of lowest cost, and then it is appropriate; if they use the ways like capital market's irregularity to get money, fabricating financial information, evading the payment of tax and so on to get the aim of lowest cost, then it is unethical behaviour. Consequently, when the enterprise makes financing, they need to follow the science, plan smarter. In the process of financing, the regular ethical problem is over-pursuing the profits, and ignoring its social responsibility, which may causes disorder in economic market and culture market.

\section{B. the appearance of ethical problems of the financing management in media companies}

The essence of unethical financing behaviour is issuers making use of asymmetry situation and use any kinds of fraud tools to make financing, tricking investors to make investments on high risk and having disadvantage on them. Now the typical appearance is making false account to get loans from the bank, and giving false profits to get "listing" qualification. At the beginning of operation in media companies, there is a big demand of capital, when there is not enough investment, they can only get loans from the bank. The loan can regularly be divided into two kinds: one kind is hypothecated loan, however, its cultural production has its own specificity, so it is not often used the other kind is joint guarantee, which is in some enterprises who have good reputation in bank, making peers guaranteeing with some good-reputation enterprises, and then make more capitals, meanwhile, lowing the risk.

At the mean time, many people also realize that media industry is a profits industry. The capital operates flexibly, when putting in a certain of capital, the profits can not be calculated and estimated in advance. This is why profit capital cost in media company is always a riddle. Some unethical media companies use this leak to get 
qualification of "listing", and through this way to get more profits. This kind of behaviour is like "making snowball", the capital becomes more and more, the risk also becomes bigger and bigger, which causes the consequence become more and more serious.

Enterprise capital management is the core of the financial management and financing is the starting point of the funds management. Facebook IPO p/e ratio is as high as one hundred times, reflecting the US stock market also have excessive speculation. Public opinion is also scariest on a high $\mathrm{p} / \mathrm{e}$ issue at home, even securities regulatory commission chairman GuoShuQing also many times declare the new shares to drop down issued p/e ratio. Even in the U.S. stock market, high price issue is also for investors to pay the price.

Facebook company listed on May 18, shares have fallen to $\$ 31$ a share after three future trading, dropped $18.42 \%$. the stock investors suffered heavy losses. Visiblely, no matter the stock market in the United States or China's stock markets, new shares high issued overdraft the investment value of listed companies with a huge investment risk. On January 9, 2011, People.Com.Cn announced prospectus. The first website IPO finally went to the front desk. Prospectus showed, PRC issued 69.1057 million shares in Shanghai stock exchange, with total share capital about 276 million strands, the financing of about 527 million yuan. When the securities regulatory commission management found "three tenors", its issue price interval 20 yuan to 22.5 yuan, the corresponding after issuance of the p/e ratio 46.13 times to 51.89 times, far higher than the same shares issued p/e ratio

In order to attract the audience's attention, some media enterprise cater to the taste of the audience and satisfy people's curiosity. They reduce the proportion of serious news, in the content with provocative, irritating crime news, disasters report, sports news, lace news as the key point, even malignant hype, etc. It is expected to become the domestic "journal first shares",since "bosom friend"spread to listing of the news. The disputes have not stayed. Some commentaries pointed out that"bosom friend" was lack of convincing in the content ,the taste, the credibility, etc. And because of its long-term published celebrity anecdotes, it have several times for violations writer and star's reputation to defend on the court, even writer BiShuMin criticized as "lack of moral bottom line", "lack of media social bear" and it shall not be listed, so voice against "bosom friend" listed is quite strong.

\section{Cause analysis on ethics issues of financing management in media enterprise}

The industry have such a evaluation and summarized for media enterprise: big investment, big return, high risk, high income. The whole industry is concerned, the media enterprise need huge money. China is experiencing a period of transition.The change of macro environment increased media enterprise financing on demand. Into the new century, with China's media response mechanism of the adjustment, in order to fit the media enterprise to establish market main body status, admittance limitation of media market capital began to loose. Monopoly industry policy loosing created conditions for Chinese media enterprise to absorb capital.Social culture environment for financing activities also have important influence in it.In recent years, due to the media industry in place of the social culture environment, the financing needs further release. Since the market economy system is imperfect, cultural environment on the effect depends on the financing activities of cultural environment adaptability and sensitivity, but also depends on the degree of the change in culture. When the macroscopic environment have such great changes conditions, microscopic changes in the environment is firstly embodies in financing subject gradually emerged, and with the various changes in the environment beganning to clear,micro main body more and more produce financing needsin different stages and levels.

Enterprise funds generally divides into self accumulation, direct financing and indirect financing. The media industry development is relatively lagging and media units is "business unit operation of enterprise", which causes the serious shortage of self accumulation and weak financial strength. With China's media industry market development and the national policy to encourage cross area expansion, the advantages of media enterprise requires a lot of money in the "horse race turf" to get ahead, which requires a lot of money for support.Self accumulation and indirect financing are difficult to solve financing gap.Listed financing and the introduction of strategic investors and direct financing means became first choice means. "For me dia enterprise, listed there is need ", ChenShaoFeng, vice President of Beijing university institute of cultural industry, said, but before the listing should have a development strategy, " in order to make enterprise develop, this should be the foothold of a media enterprise listing, rather than blindly" circle money". It is a pity that enterprise listed purpose almost to encircle money in Chinese .The securities investors strongly protest, including media enterprise. Rate of change of some companies shows in Fig .1.

\begin{tabular}{|c|c|c|c|c|c|}
\hline ntem & company вал" & $\begin{array}{l}\text { 1atr it } \\
\text { changedie }\end{array}$ & \begin{tabular}{|l|} 
att af af \\
changesze
\end{tabular} & $\begin{array}{l}\text { Iate of } \\
\text { changess }\end{array}$ & $\begin{array}{l}\text { nate if } \\
\text { changeste }\end{array}$ \\
\hline $\begin{array}{l}\text { tries } \\
\text { mongy nate of }\end{array}$ & $\begin{array}{l}\text { China Tetevsion } \\
\text { Moba? }\end{array}$ & 3.275 & 16.9256 & $316 \%$ & $3.26 \mathrm{k}$ \\
\hline chroe & DianGuang media & $26300 \%$ & $20335-1$ & $39.90 \% \mathrm{~F}$ & $200 \%$ \\
\hline maininacume : & GeHER CABLF. & todseri & 11.6744 & $10.64 \mathrm{k}^{2}$ & $4.405 \mathrm{~s}$. \\
\hline $\begin{array}{l}\text { raise moeey } \\
\text { - wate } \\
\text { of }\end{array}$ & $\begin{array}{l}\text { Chins Telertion } \\
\text { Mresa. }\end{array}$ & $125 \%$ & 4002 & 35460 & 73496 \\
\hline chang: of per & DiauGiang Mesa f & t192m & soster & -6325 & $4026 \%$ \\
\hline profic. & GeHLaCABLE, & 27996 & $000 \mathrm{~s}$ & 7.1035 & 2674 \\
\hline $\begin{array}{l}\text { naser money } \\
\text { tats }\end{array}$ & 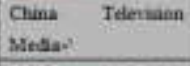 & 22296 & $164 \times 6=$ & +315 & $2509 \%$ \\
\hline chang of att & DianOuans Medac & 0.1246 & $38846+$ & 60.034 & 55.7958 \\
\hline $\begin{array}{l}\text { buenen } \\
\text { activitien. }\end{array}$ & CelleacABLE & 385960 & 928460 & 14.8364 & $7238 \mathrm{sef}$ \\
\hline
\end{tabular}

Figure 1. Three big rate after media companies listed

Note: time to market for $\mathrm{T}, \Delta \mathrm{n}$ stands for relative to the rate of " $\mathrm{T}+\mathrm{n}$ "change of " $\mathrm{T}+\mathrm{n}-1$ ".

Competition pressure source of media enterprise can be roughly divided into three basic aspects: the first is the content,which is to spread the content of the original ability and the content of integrated configuration. The second is channel, which is for communication channel. The third is terminal, which is for terminal service chain industry chain and value chain expansion. Malignant competition of media enterprise results in the news ethics moral decay, also worsen the relationship between the people and media, media credibility sell at a discount greatly. According to the statistics of press and publication 
administration, by the end of 2009, China television stations are from thirty eight to three hundreds and fiftyfour houses in $1980 \mathrm{~s}$, a total of three thousands five hundreds and ninety-five .Television channels and radio stations are from one hundred and fourteen to three hundred and four in1980 s, a total of one thousand nine hundred and thirty-four programs.Media market expansion is not balanced and it lacks the competition standard. Media ethics is a common disorder.

\section{CONCLUSION}

Ethical issues of enterprise financing are the product by organic combination of the financial economic ration and moral ration. In the new competitive environment ,this financial theory helps financial management to form form the correct ideas.From the practice level speaking, this study will help our media enterprise to enhance effectiveness, and will contribute to the current enterprise to contain and solve these behavior,such as,financing debt evasion, false information, credit anomie etc.

\section{REFERENCES}

[1] John,The Media Of Mass Communicatian ,6th ed,Boston :Allen Bacon,2006:721 731 .

[2] Edith,T. Penrose The Theory of Growth of the Firm , New York:Oxford University Press,2008 : 43 58

[3] WangQing. Analysis on ethics lack of China's capital market [J]. Science of Finance and Economics, 2006 (8) : 7

[4] Wang SuLian, Ke Dagang. Study about financial ethics model [J]. Financial Research, 2006 (5) : 37

[5] Zhou Zucheng. Management and Ethics. Beijing: Tsinghua University Press, 2000

[6] Clarence Walton. Developing the corporate ethic.Ethical Issues In Business, 1983

[7] Chen LiHao, Wang DiHua. Enterprise financial ethics to explore [J].Social Science Front, 2008 (7) : 63

[8] ZhangJuan. Analysis on financial supervision and ethical norm form rationality. Financial Issue (accounting), 2005 (1) : 20

[9] Wei YongZheng. Media call capital rule of law [J].Eexploration and Schools of Thought Contend, 2007 (2) : 45-50

[10] Zhong YuanYuan, XiaoYi.Media responsibility of the ethical appeal. Journal of lanzhou, 2009 (12) : 2 